\title{
Review of Philippe Steiner's Durkheim and the birth of economic sociology (Trans. Keith Tribe). Princeton (NJ): Princeton University Press, 2011, 249pp.
}

\author{
JARED L. PEIFER \\ Rice University
}

Émile Durkheim believed that even the seemingly individual act of "thinking" is a social activity (Calhoun, et al. 2007, 142). Philippe Steiner extends this Durkheimian emphasis on societal level explanations to the burgeoning field of economic sociology. Just as thinking depends upon external categories and meanings provided by society, Durkheim instructs us that we likewise cannot truck, barter, or exchange without knowledge that is inscribed by society.

This is the first book on Durkheim's economic sociology, perhaps because Durkheim was less than explicit in his intent to create such a subfield. Steiner, a prominent Durkheimian scholar, shows that simply reading Durkheim's four most popular books that are translated into English-The division of labor in society (1893); The rules of sociological method (1895); Suicide (1897); and The elementary forms of religious life (1912) - will not yield a comprehensive view of Durkheim's economic sociology. Instead, Steiner expertly marshals period journals, including Durkheim's own journal L'Année Sociologique, and Durkheim's personal letters to fill in the holes. True to his communitarian sensibilities, Durkheim did not carry out his economic sociology project alone. Steiner shows how Durkheim's students, Marcel Mauss, Maurice Halbwachs, and François Simiand (among others), pushed his economic sociology research project forward during and after their tutor's lifetime. Since these scholars are more commonly studied by anthropologists, Steiner unearths fresh classical material for economic sociologists.

The original French version of Steiner's book is entitled, L'école Durkheimienne et l'économie: sociologie, religion et connaissance (2005). This more comprehensive title, roughly translated Durkheim's school and the economy: sociology, religion, and knowledge, clearly signals the important role religion plays in Steiner's interpretation of Durkheimian economic sociology. Present day sociologists have specialized in their 
respective subfields (such as the sociology of religion and economic sociology) and have consequently mostly ignored the relationship between these seemingly disparate realms. Steiner presents the case that not only Weber, but Durkheim too, placed great importance on the relationship between religion and the economy.

Max Weber is widely viewed as the first economic sociologist (Swedberg 2011), so Steiner's argument that Durkheim also deserves such credit makes this book of special interest to scholars in the subfield. Despite the attention both Weber and Durkheim paid to economy and society, few early sociologists focused on the economy. In fact, Talcott Parsons, a towering sociologist of the mid twentieth century is reported to have made an influential pact with economists along the lines of, "You, economists, study value; we sociologists, will study values. You will have claim on the economy; we will stake our claim on the social relations in which economics are embedded" (Stark 2009, 7). After a long period of dormancy, the field of 'new economic sociology' sprang up in the 1980s. Accepting the risk of over simplification, this sociological subfield largely rallies around 1) articulating a critique of neoclassical theory, and 2) fashioning a more positive social scientific theory of how sociological factors explain economic phenomena.

While Durkheim is rarely associated with the subfield of economic sociology, he is often closely associated with the sociology of religion, stemming mostly from his tour de force, The elementary form of religious life (1912). There Durkheim erects a functional definition of religion, whereby we recognize religion whenever social actors come together in unified attention to something that is larger than themselves. The accompanying emotional states of this unified social activity denote the sacred (i.e., religion), which Durkheim pitted against the profane (e.g., mundane economic activity). Durkheim instructs sociologists of religion to abandon more substantive definitions of religion (such as Weber's) and recognize the "religious" or "sacred" in unexpected places.

Durkheim is also considered a seminal secularization theorist, asserting that "if there is one truth that history has incontrovertibly settled, it is that religion extends over an ever diminishing area of social life" (1966 [1893], 118). In this particular instance, Durkheim is referring to the organized institution of religion (e.g., Catholicism), not his functional notion of religion. Assessing the veracity of the secularization 
thesis has kept many sociologists of religion busy for nearly half a century.

\section{SUMMARY OF THE BOOK}

Steiner argues that Durkheim's economic sociology consists of two research programs. The first is a critique of political economy, or the economists of his day. The second sees Durkheim turn to religion, instead of the economy, as the key to understanding society. The first two chapters outline each program in turn. Chapters 3 to 6 demonstrate how these programs were taken up by Durkheim's students. The final two chapters of the book focus on extending the material covered to an economic sociology of knowledge, with an emphasis on the schooling system. Here Steiner enters into dialogue with performativity scholarship, a growing area of interest among economic sociologists.

\section{First research program: critique of political economy}

Durkheim's first program of economic sociology articulated a critique of political economists for their penchant for reductionism, wherein complex social reality was replaced with simplistic assumptions of rational actors operating outside of society. However, Durkheim did not stop there. Similar to Durkheim's broader conception of a "social fact", which refers to "ways of acting, thinking, and feeling external to individual consciousness that are imposed upon individuals" (p. 22), Durkheim's economic sociology focuses on societal level "economic facts". For instance, Durkheim argues that a contract is more than the sum of each party's self-interest, "but is possible only thanks to the regulation of contracts, which is of social origin" (Division of labor, quoted in Steiner 2011, 28).

Durkheim also envisioned a moral component to his conception of economic fact. Namely, a healthy society's collective conscience constrains immoral economic behavior. For Durkheim though, modern industrial society was unhealthy. To fill this moral regulative void, Durkheim proposed a new social institution he called the "professional group". This was to be an association of workers within the workplace that would create cohesion, restrain individual passions and foster a principle of justice. This was Durkheim's early attempt to envision a remedy to the immoral aspects of the modern world.

Simiand and Halbwachs, both students of Durkheim, were principal contributors to the economic sociology section of L'Année Sociologique 
for almost 50 years (1897-1942), extending Durkheim's critique against the orthodox economists of their day. Most importantly, they "put forward an approach that would draw upon empirical investigation together with contributions from history, statistics and sociology" (p. 107). Three of the book's eight chapters are comprised of long, detailed analysis of the work of Durkheim's students. Incidentally, this raises the question in the reader's mind about how much of the school of economic sociology Steiner outlines should really be credited directly to Durkheim.

\section{Second research program: religion and the economy}

In his doctoral dissertation, which was published as Division of labor in 1893, Durkheim looked to the economy to address his perennial concerns regarding societal cohesion, particularly focusing on 'organic solidarity', the interdependence stemming from vocational specialization. However, just a couple of years after finishing his dissertation, Durkheim dramatically announced an important change in his intellectual orientation in a letter to the editor of a periodical.

It was in 1895 that I clearly understood the leading role played by religion in social life. It was in this year that, for the first time, I found a means to approach the study of religion sociologically. This was a revelation to me (quoted in Steiner 2011, 39).

Durkheim disagreed with the Marxian notion that the economy could be at the root of society. Instead, Durkheim set out to show that religion was the foundation from which the economic grew. In the closing pages of Elementary forms Durkheim writes, "the idea of economic value and that of religious value cannot be unrelated, but the nature of these relationships has not yet been studied" (quoted in Steiner 2011, 58). While this "revelation" was an important event, Steiner makes the case that it did not bring an end to Durkheim's interest in the economy.

While Durkheim never completed his project for linking religion to his economic sociology, Steiner argues that Durkheim's nephew, Marcel Mauss, did. In The gift, Mauss (1923) focuses on a unique kind of economic exchange (i.e., gift exchange) that comprises both interest and disinterest; egoism and altruism. This particular form of exchange can be aptly approached from the perspective of multiple societal spheres: religion (gifts to the gods), economy (exchanging goods), and family (dowries). This leads Mauss to the concept of a total social fact, which 
tells us no sphere of social life is more fundamental than any other. Steiner argues that Mauss's conclusion parts ways with Durkheim's contention that religion is more essential than the economy (when it comes to explaining the origins of social life.)

While Mauss's stalemate answer (neither religion nor the economy trumps the other) may have been satisfying to its first readers, who were also interested in the origins of society, it strikes me as somewhat less than satisfying. Steiner does not end his story here, however. He emphasizes how Durkheim's "sociology of knowledge" provides a more intriguing link between the sociology of religion and economic sociology. Durkheim believed social action (or social reality) is necessarily preceded by knowledge. The prime examples being religion and myth, which, in Steiner's words, "make and express social reality in one move, and do so through the intermediary of symbols that unite different individual consciousnesses so that they might communicate and feel things in unison" (p. 177). Durkheim sees the schooling system replacing organized religion's role in producing knowledge. As such, the educational institution actively creates the knowledge that is planted in the next generation's heads and also takes over the reins of society's moral order from organized religion. Here we see Durkheim's secularization thesis taking shape.

In a clever thought experiment, Steiner considers how Durkheim's economic sociology might provide a more comprehensive explanation of how the modern profit-driven "economic man" came into being. Weber's (1930) Protestant ethic and the spirit of capitalism explains the religious spark that helped start modern rational capitalism, but acknowledges that those religious forces quickly dissipated. What sustained capitalism in the following centuries? Durkheim's emphasis on sociology of knowledge answers that "capitalism cannot survive without ideological support" (p. 213) and "that the schooling system plays a decisive role when it becomes a central institution through which the cognitive capital embodied in the individual is produced" (p. 213).

\section{Performativity}

It is with this emphasis on the education system that Steiner most directly engages with current day performativity scholarship, a growing area of interest within economic sociology. Performativity scholars seek to uncover the extent to which economic knowledge is helping create 
(or 'perform') economic actors whose behavior often approximates that of the caricatured utility maximizer. As MacKenzie (2006) puts it, economic theory is better depicted as An engine, not a camera (the title of his book exploring how financial markets put economic theory into action).

For instance, Simiand shows how Fredrick Taylor's theory of scientific management in the 1920's produced the institutions that fostered its rational behavior. This peculiar workplace environment came about "not because of some miraculous coincidence of the ideal of an isolated theorist and the society's law of progress, but rather through social inscription of theory in institutions in whose terms individuals are led to act in the economic world" (p. 187).

Steiner's emphasis on economic experts as central performative actors in the economy closely follows the present day performativity research program. But this narrow implementation of performativity theory is tantamount to consideration of religious ideals only as they apply to clergy. The education system, broadly speaking, has the potential to inculcate economic knowledge to a much larger swath of social actors, not just those with formal economic training. Steiner's emphasis on the education system shows promise for a wider application of performativity theory.

Steiner's overtures to performativity scholarship will be of great interest to economic sociologists. Does Durkheim's work and that of his students provide a sufficient foundation for performativity scholars? Will it push the field in new directions? I would like to have seen Steiner engage with questions of this nature more systematically. Nonetheless, economic sociologists owe Steiner a debt for formally introducing Durkheimian thought into the subfield's institutional repertoire. In true Durkheimian fashion, and the mark of good scholarship, Steiner leaves ample room for creative research to grow.

\section{REFERENCES}

Calhoun, Craig, Joseph Gerteis, James Moodly, Steven Pfaff, and Indermohan Virk (eds.). 2007. Classical sociological theory. Malden (MA): Blackwell Publishing.

Durkheim, Émile. 1966 [1893]. The division of labor in society. New York: The Free Press.

MacKenzie, Donald A. 2006. An engine, not a camera: how financial models shape markets. Cambridge (MA): MIT Press.

Stark, David. 2009. The sense of dissonance: accounts of worth in economic life. Princeton: Princeton University Press. 
Steiner, Philippe. 2005. L'école Durkheimienne et l'économie: sociologie, religion et connaissance. Geneva: Librairie Droz.

Swedberg, Richard. 2001. Max Weber's central text in economic sociology. In The sociology of economic life, eds. M. Granovetter, and R. Swedberg. Boulder (CO): Westview Press, 62-77.

Jared L. Peifer is a postdoctoral fellow in the sociology department at Rice University. He specializes in economic sociology and sociology of religion with a particular focus on how social actors bring these two realms together in their everyday lives. More specific research projects include analyzing the economic and sociological determinants of monetary contributions to local congregations, and investor loyalty to religiously affiliated mutual funds in the United States.

Contact e-mail: <jared.peifer@rice.edu> 